African Crop Science Journal by African Crop Science Society is licensed under a Creative Commons Attribution 3.0 Uganda License. Based on a work at www.ajol.info/ and www.bioline.org.br/cs DOI: https://dx.doi.org/10.4314/acsj.v28i1.5S

\title{
ANTAGONISTIC EFFECTS OF BIOCONTROL AGENTS AGAINST Phytophthora infestans AND GROWTH STIMULATION IN TOMATOES
}

\author{
W.G. KARIUKI, N.W. MUNGAI' ${ }^{1}$ D.O. OTAYE, M. THUITA² ${ }^{2}$ E. MUEMA², H. KORIR ${ }^{1}$ \\ and C. MASSO ${ }^{2}$ \\ Department of Biological Sciences, Egerton University, P. O. Box 536-20115, Egerton, Kenya \\ ${ }^{1}$ Department of Crops, Horticulture and Soils, Egerton University, P. O. Box 536-20115, \\ Egerton, Kenya \\ ${ }^{2}$ International Institute of Tropical Agriculture (IITA), P. O. Box 30772-00100, Nairobi, Kenya \\ Corresponding author: gracekariukib@gmail.com
}

\begin{abstract}
Late blight disease is a major cause of economic losses in tomato (Lycopersicon esculentum L.) production in eastern Africa. The objective of this study was to evaluate the efficacy of Trichoderma species in controlling late blight disease and their role on the growth of tomato. Trichoderma asperellum and T. harzianum were isolated from two commercial products containing the antagonistic species. Culture-based and molecular approaches, genomic DNA isolation and amplification, using ITS1 and ITS4 universal primers, and sequencing, were used to characterise the products. Trichoderma antagonistic effects against Phytophthora infestans (causative of tomato late blight) experiments were conducted in vitro and in the greenhouse. The greenhouse experiment had five treatments; namely, a negative control, Metalaxl-M, T. asperellum, T. harzanium and mixture of the two biocontrol agents, laid out in a randomised complete block design. The experiment was carried out for 12 weeks, with 3 weeks measurements intervals. Morphological and molecular characterisation confirmed the organism in most of the commercial products as T. harzianum and T. asperellum. An inhibiting action was observed on the $P$. Infestans mycelial growth, by the effect of T. asperellum (30.7\%), and $T$. harzianum (36.9\%).Trichoderma spp. suppressed late blight disease in the greenhouse experiment. These effects were specific to soil type, with the higher effectiveness realised in Ferralsols (27\% disease severity) and least in Nitisols (36\% disease severity). Trichoderma harzianum and $T$. asperellum resulted in higher above ground biomass of tomato of 31 and 19\% increase over the control, respectively. There is potential of biocontrol agents in reducing P. infestans effects in tomatoes and in stimulating growth.
\end{abstract}

Key Words: Ferralsols, Lycopersicon esculentum, Metalaxl-M, Trichoderma asperellum

\section{RÉSUMÉ}

La maladie du mildiou est une cause majeure de pertes économiques dans la production de tomate (Lycopersicon esculentum L.) en Afrique de l'Est. L'objectif de cette étude était d'évaluer l'efficacité des espèces de Trichoderma dans la lutte contre le mildiou et leur rôle sur la croissance de la tomate. 
Trichoderma asperellum et $T$. harzianum ont été isolés de deux produits commerciaux contenant les espèces antagonistes. En se basant sur la culture et des approches moléculaires, l'isolement de l'ADN génomique et l'amplification, en utilisant des amorces universelles ITS1 et ITS4, et le séquençage ont été utilisés pour caractériser les produits. Des effets antagonistes de Trichoderma contre Phytophthora infestans (causant le mildiou de la tomate) ont été menés in vitro et en serre. L'expérience en serre a eu cinq traitements; à savoir, un contrôle négatif, Metalaxl-M, T. asperellum, $T$. harzanium et un mélange des deux agents de lutte biologique, disposés dans un modèle de bloc complet randomisé. L'expérience a duré 12 semaines, avec des intervalles de mesure de 3 semaines. La caractérisation morphologique et moléculaire a confirmé l'organisme dans la plupart des produits commerciaux comme T. harzianum et $T$. asperellum. Une action inhibitrice a été observée sur la croissance mycélienne de $P$. Infestans, sous l'effet de T. asperellum (30,7\%) et T. harzianum (36,9\%). Trichoderma spp. supprimé la maladie du mildiou dans l'expérience en serre. Ces effets étaient spécifiques au type de sol, avec une efficacité plus élevée réalisée dans les Ferralsols (27\% de gravité de la maladie) et moins dans les Nitisols (36\% de gravité de la maladie). Trichoderma harzianum et $T$. asperellum ont entraîné une augmentation de la biomasse aérienne de la tomate de 31 et 19\% par rapport au témoin, respectivement. Les agents de lutte biologique peuvent réduire les effets de $P$. infestans sur les tomates et stimuler la croissance.

Mots Clés: Ferralsols, Lycopersicon esculentum, Metalaxl-M, Trichoderma asperellum

\section{INTRODUCTION}

Late blight disease, caused by Phytophthora infestans (Mont.) de Bary, is among the most economically significant diseases of tomato,accounting for up to $90 \%$ losses in east Africa (Masinde et al., 2011). The disease affects leaves, stems and fruits of tomato. Some of the control measures used include use of fungicides, crop rotation, utilisation of certified seeds and promotion of resistant cultivars.

Use of fungicides is effective, but is characterised by repeated applications (i.e., 57 days intervals), which is costly, and timeconsuming (Momanyi et al., 2019; Lamichhane et al., 2020). This is in addition to development of fungicide resistance and high virulence of the pathogen, hazardous residue accumulation in fruits and decline of useful soil microbes (Heneberg et al., 2018; White et al., 2019). Harmful effects to humans, if proper protection is not administered while spraying, and environmental pollutions are other associated problems (Gyawali, 2018; Lamichhane et al., 2020).
Plant growth promoting fungi (PGPF), like Trichoderma harzianum and Tricoderma asperellum are considered potential biological control agents (BCA) of soil borne pathogens such as $P$. infestans, and therefore, offer an alternative strategy to use of inorganic fungicides (Sharma, 2018; Mbuthia et al., 2019). Other pathogens controlled by Trichoderma spp. include Fusarium, Pythium, Sclerotinia, Botrytis and Rhizoctonia (Sharma, 2018).

The modes of action of the BCAs include antibiosis, mycoparasitism, enzyme activity, competition and plant defence induction (Ghorbanpour et al., 2018; Latz et al, 2018; Köhl et al., 2019). As a result, increased plant nutrients absorption, increases in biomass of roots and shoots, increased leaf area as well as productivity of tomato and other crops have been observed (Chowdappa et al., 2013; Singh et al., 2013).

In view of the potential of the BCA to control soil borne pathogens, most agro-based industries and suppliers have flooded the market with a lot commercial BCA-based products. However, the claim of effectiveness of quite a number of these commercial 
products have not been substantiated which may lead to poor quality products sold to farmers. The objective of this study was, therefore, to isolate, screen and test the efficacy of commercial growth promoting $T$. harzianum and T. asperellum used as biocontrol agents against $P$. infestans on tomatoes in three different soil types in Kenya.

\section{MATERIALS AND METHODS}

Isolation of Trichoderma. Trianum- $P$ and Trichotech commercial bioproducts were obtained by the International Institute of Tropical Agriculture (IITA), Nairobi, from the manufacturers and suppliers, respectively. A total of 18 product samples were purchased, 9 each for Trianum-P and Trichotech. They were labelled GK1-GK9, which included three batches (87LV3536, 87TP2423, 87TPP2433) with three product samples per batch for Trianum- $\mathrm{P}^{\circledR}$ and nine product samples from one batch $(51 / 013)$ of Trichotech ${ }^{\circledR}$ that were GK10-GK18 (Table 1).

Isolation of Trichoderma strains was carried out as described by Carter (2011), with modifications. A ten-fold serial dilution technique was used, whereby $1 \mathrm{~g}$ per sample was suspended in $9 \mathrm{ml}$ of physiological water ( $9 \mathrm{~g}$ of Nacl dissolved in $1000 \mathrm{ml}$ of distilled water). A $0.1 \mathrm{ml}$ from $10^{-4}, 10^{-5}, 10^{-6}$ and $10^{-7}$ dilutions were spread plated on Rose Bengal agar, supplemented with $1 \mathrm{~g} \quad \mathrm{~L}^{-1}$ chloramphenicol (antibiotic), and then incubated for 4 days in the dark at $28{ }^{\circ} \mathrm{C}$.

To identify the Trichoderma spp., its distinctive morphological characteristics were monitored. Microscopic characteristics of shape, size, arrangement as well as the development of conidiophores and phialides were also checked. Furthermore, macroscopic examination was done by growing $T$. harzianum and T. asperellum on Potato Dextrose Agar (PDA) for 5 days. The mode of mycelia growth, colour of spores and changes of medium pigmentation for each isolate was examined daily. The isolated Trichoderma spp. on Rose Bengal media were stored at $-20^{\circ} \mathrm{C}$ in a $10 \%$ glycerol for further analysis.

Screening of isolates. DNA was extracted from three-days old pure cultures of Trichoderma strains, grown on Rose Bengal media according to Carter (2011). The DNA stuff was air-dried in a sterilised fume chamber; re-suspended in $50 \mu$ l sterile double distilled water and stored at $-20{ }^{\circ} \mathrm{C}$ for further analysis.

Amplification of the internal transcribed spacer (ITS) region of rDNA of fungal isolates was carried out by polymerase chain reaction (PCR), with universal primer pair ITS1 (5' TCCGTAGGTGAACCTGCGG-3') and ITS4 (5' - TCC TCCGCTTATTGATATGC-3' (Gelfand and White, 1990). PCR was performed in $25 \mu \mathrm{l}$ and for each run; negative controls (no template DNA) were used to test for contamination in the reagents. Confirmation of the PCR products was done by electrophoresis on $2 \%(\mathrm{w} / \mathrm{v})$ agarose gel in $1 \mathrm{X}$ Tris Borate-EDTA buffer, and stained with ethidium bromide (3.4 g) at 150 volts for one hour. Visualisation and photographing of the gel was done under UV trans-illumination gel documentation system, respectively. Purification of the amplified PCR products was done using Thermo Scientific Gene Jet

TABLE 1. Characteristic of the three site soil types used for the greenhouse efficacy trial

\begin{tabular}{llcccc}
\hline Source of sample & Soil classification & $\mathrm{pH}\left(\mathrm{H}_{2} 0\right)$ & Org. C $(\%)$ & $\mathrm{N}(\%)$ & $\mathrm{P}\left(\mathrm{mg} \mathrm{kg}^{-1}\right)$ \\
\hline Bungoma & Ferralsols & 6.0 & 2.43 & 0.24 & 35.0 \\
Chuka & Rhodic nitisols & 5.8 & 2.46 & 0.16 & 14.0 \\
Egerton & Vitric andosols & 6.3 & 3.62 & 0.21 & 43.6 \\
\hline
\end{tabular}


PCR purification kit K0702, and run on electrophoresis as described above, to checked for purity and molecular size (600bp) using a $1000 \mathrm{bp}$ ladder. The purified products were sequenced at Segolip unit of the BeCa hub, ILRI. The universal primers: ITS1 (5' TCCGTA-GGT-GAA-CCT-GCG-G 3') and ITS4 (5' TCC-TCC-GCT-TAT-TGA-TAT-GC 3') were used (Gelfand and White, 1990).

The sequences generated were edited and analysed for phylogenetic relationships, using the Molecular Evolutionary Genetic Analysis software (MEGA, version 6.0) (Tamura et al., 2013). The sequences were submitted to National Centre for Biotechnology Information (NCBI) GenBank, New York, USA, for identification. The similarity coefficients were subjected to Unweighted Pair Group Method with Arithmetic mean (UPGMA), to cluster the isolates based on their overall similarities. Multiple sequence alignments of the consensus sequences were performed using clustal W (Larkin et al., 2007). The maximum-likelihood (ML) phylogenetic analysis of multiple aligned sequences with bootstrap values for 1000 bootstrap replicates was performed using SeaView software version 4.0 (Galtier et al., 1996).

Isolation and identification of Phytophthora infestans. Late blight infected tomato plants leaves were collected from Field 3 at Egerton University, Njoro, and used for isolation of $P$. infestans. The infected tomato leaves were surface-sterilised with $70 \%$ ethanol for one minute, then in 5\% sodium hypochlorite for five minutes, and finally washed three times in sterile water to remove the surfacesterilants.

A potato tuber was washed with tap water, peeled off with a knife and surface-sterilised with $70 \%$ ethanol. The tuber was sliced into pieces of about $0.5 \mathrm{~cm}$ thickness. The surfacedisinfected leaves were cut into small pieces having some infected and some healthy tissues. The pieces of leaves were placed in between two potato tuber slices, using sterilised forceps. The two potato slices with the late blight affected leaves sandwiched were put in a petri-dish having a filter paper and incubated inside an incubator at $19{ }^{\circ} \mathrm{C}$ for seven days for the pathogen to grow. Thereafter, the mycelia was used in the $P$. infestans identification process.

A hundred and fifty millilitres of clarified V8 juice was centrifuged at $6000 \mathrm{rpm}$ for 5 minutes. The V8 based media was prepared using $100 \mathrm{ml}$ of the centrifuged V8 juice supernatant, mixed with distilled water $(900$ $\mathrm{ml}), \mathrm{CaCO}_{3}(2 \mathrm{~g})$ and agar (15 g), and autoclaved at $121^{\circ} \mathrm{C}$ for 15 minutes (Nourulaini et al., 2012). A plug of the grown mycelia was placed on the V8 based media and allowed to grow for 7 days. Sub-culturing was done on malt extract (ME) agar, supplemented with $5 \mathrm{~g} \mathrm{l}^{-1}$ chloramphenicol and incubated at $25^{\circ} \mathrm{C}$ for three weeks. Identification of $P$. infestans was done based on morphology (i.e., sporangium, sporangiophore, hyphae and the presence or absence of clamydospores).

\section{Efficacy tests of T. harzianum and $T$. asperellum}

In vitro antagonistic tests. The antagonism experiment was arranged in a completely randomised design (CRD), with three replications. The antagonistic effects of $T$. harzianum and T. asperellum were evaluated against $P$. infestans, using the dual culture method (Fatima et al., 2015).

For the inhibition assays by the Trichoderma strains, approximately $5 \mathrm{~mm}$ diameter of seven day old agar plug (mycelial discs) of the pathogen and Trichoderma strains were cut using a sterilised cork borer and placed at equal distances from the periphery on PDA petri dishes. The plates were incubated at $25^{\circ} \mathrm{C}$ for eight days and the diameter growth of the pathogen measured daily. The mycelial mats of Trichoderma strains and $P$. infestans were gently picked with a needle for hyphal microscopic interaction examination. The zone of inhibition in the 
diameter of the colony growth was also calculated using the following Equation (Perveen and Bokhari, 2012):

Inhibition Percentage $I P=\frac{(C-T)}{C} \times 100$ Where:

$I P=$ inhibition percentage; $C=$ mean colony diameter $(\mathrm{mm})$ of the growth in the control treatment; and $T=$ mean colony diameter $(\mathrm{mm})$ of the growth in the treatment tested. Greenhouse study

Soil chemical analysis. The soil from three sites, namely the Rift valley (Egerton), Eastern Kenya (Chuka) and Western Kenya (Bungoma) in Kenya, were air-dried, prepared and analysed using standard procedures as described by Okalebo et al. (2002), and the results are presented in Table 1 . Soil $\mathrm{pH}$ ranged from 5.8 to 6.3 , which are slightly acidic, with Eastern Kenya site having lower values. Nitrogen was lowest in the Nitisols at $0.16 \%$ and highest at Ferralsols at $0.24 \%$. Total carbon was least in Ferralsols $(2.43 \%)$, but highest in Andosol (3.62\%). Available Pranged between 14 and $43.6 \mathrm{mg} \mathrm{kg}^{-1}$ for Nitisols and Ferralsols, respectively (Table 1).

Establishment of the experiment. Tomato seedlings nursery bed was established by sowing tomato seeds in the greenhouse.A plastic pot $(15.5 \mathrm{~cm}$ diameter and $35.4 \mathrm{~cm}$ height) was used. The plastic pots were filled with $5 \mathrm{~kg}$ of solar dried soil from the three sources. The experiment contained five treatments, namely a negative control (distilled water-T0), fungicide (Ridomil ${ }^{\circledR}$ (Metalaxl-M) - T1) which was used as a standard check, $T$. harzianum (Trianum- ${ }^{\circledR}{ }_{-} \mathrm{T} 2$ ); T. asperellum (Trichotech $^{\circledR}-$ T3) and mixture of the two biocontrol agents T1+T2 (T4). The experiment was arranged in a complete randomised block design (RCBD), with three replications. Diammonium phosphate (DAP) (18-46-0) mineral fertiliser was applied as per the recommendations (10 g per plant) during transplanting (Starke Ayres, 2014).

Fourteen day old healthy seedlings were transplanted into the plastic pots. The treatments were introduced to the potted seedlings according to the manufacturers' recommendations, which was $3.0 \mathrm{~g} \mathrm{l}^{-1}$. This was repeated at two weeks interval at half the initial dosage $\left(1.5 \mathrm{~g} \mathrm{l}^{-1}\right)$. Distilled water was used to maintain the soil moisture content.

The pathogen ( $P$. infestans) spores were stained using cotton blue and counted using a haemocytometer. Three days after transplanting and treatment of the seedling in the pots, $300 \mathrm{ml}$ suspension $\left(1 \times 10^{6} \mathrm{CFU} \mathrm{g}^{-1}\right)$ of $P$. Infestans was introduced to all the treatments (Poornima, 2011).

Late blight severity and percentage of survival of healthy plants were assessed at 30 days after transplanting. The number of healthy plants and diseased leaves were used to determine late blight severity. One stem was randomly selected in every pot and tagged for assessments, once in a week, for a period of 12 weeks. Disease severity proportion of leaf area diseased or the percentage leaf area infected by late blight were estimated from the five leaves between the $3^{\text {rd }}$ and $7^{\text {th }}$ leaf (from the top) on each of the sampling stem. The area under disease progress curve (AUDPC) was calculated using the following formula, based on percent leaf infection (Haynes and Weingartner, 2004);

$$
A U D P C=\sum_{i=1}^{n-1} \frac{y_{i}+y_{i+1}}{2} \times\left(t_{i+1}-t_{i}\right)
$$

Where:

$y_{i}=$ an assessment of a disease (percentage) at the $i^{\text {th }}$ observation; $t_{i}=$ time (in days) at the $i^{\text {th }}$ observation; and $n=$ the total number of observations.

The shoot dry weights were determined by cutting the above ground portion of the plants and drying them at $65^{\circ} \mathrm{C}$ for 72 hours 
and dry weights measured. Analysis of variance was performed on the data using the Generalised Linear Model (GLM) of the Statistical Analysis Software programme, SAS (SAS Institute, 2014). Treatments means were compared using Least Significant Differences (LSD) at $\mathrm{P}<0.05$.

\section{RESULTS}

Morphological characteristics of the biocontrol agents. The morphological characteristics of $T$. Harzianum consisted of formation of white concentric rings (Fig. 1A). Wavy edged colonies of $8-9 \mathrm{~cm}$ diameter were measured across both media, which indicated a rapid growth rate. After four days, white mycelia without conidia grew in the PDA media; while conidia (green spores) were produced in the Rose Bengal media. The reverse colony colour was pale yellow. Paired primary coniodiophore branches and phialides held in whorls of 2 to 3 at $90^{\circ}$ angle, were observed at $\mathrm{x} 400$ under a compound microscope. In addition, conidiophores with short side branches, which assumed pyramidal aspect, short inflated phialides, and smooth and small conidia patterns were observed.

The morphological characteristics of $T$. Asperellum observed on PDA media were the formation of white concentric ring (Fig. 1B). Smooth edged colonies of $8-9 \mathrm{~cm}$ diameter were measured, which indicated a rapid growth rate of the T. Asperellum. Four days after incubation, white mycelia and conidia were produced. The reverse colony colour was also pale yellow. Paired primary conidiophore branches and phialides held in whorls of 2 to 3 at $90^{\circ}$ angle, were observed at $x 400$ under a compound microscope. Some phialides were flask-shaped, while others were solitary with cylindrical and sharply constricted at the tips. A detached mass of conidia was observed. The morphological characteristics from each of the different batches of the commercial products were similar in all the plates. Hence, molecular characterisation was done to identify the different species.

Identification and genetic diversity of Trichoderma spp. Out of the eighteen isolates of Trichoderma spp., i.e., GK1-GK9 for T. harzianum and GK10-GK18 for T. asperellum; only GK2R, GK7R, GK8R, GK9 and GK15 had positive single band on DNA-PCR analysis. Based on partial or contig alignment blasting of the ITS1-5.8S-ITS4 DNA, region, GK2 and GK8, reverse strands were identified as $T$. harzianum with $>90 \%$ identity; while GK7 reverse (95\%) and GK9 (contig alignment)

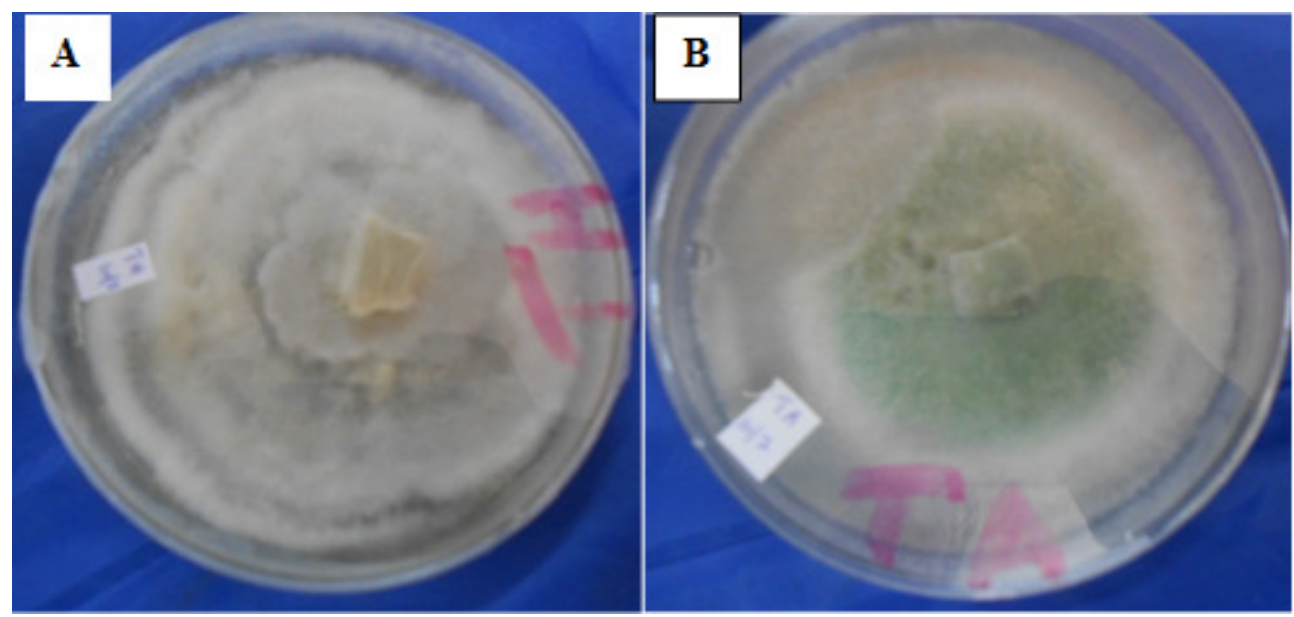

Figure 1. Morphological characteristics of the T. harzanium (A) and T.asperellum (B). 
(92\%) identities were classified as Meyerozyma caribbica. GK15 (contig alignment) was identified as T. Asperellum with a $90 \%$ identity (Table 2).

For the phylogenetic analysis, only GK9 and GK15 isolates which had shown positive contig alignment on blasting were used. Further identification showed that GK15; which had been identified as T. Asperellum (Table 2), was clustered with the other Trichoderma strains. On the other hand, GK9, which had been identified as $M$. caribbica (Table 2) was confirmed not to be a relative of Trichoderma spp. All the other strains used in the phylogenetic tree were outgroups of Trichoderma spp. (Fig. 2).

Identification of $\boldsymbol{P}$. infestans. A lemon-shaped sporangia, which is semi-papillae type which produces zoospores, was observed. It also had profusely branching mycelia which were aseptate.

In vitro evaluation of antagonists. Trichoderma harzianum and T. asperellum significantly reduced $P$. infestans growth under the in vitro conditions (Table 3 ). The interactions between the antagonists and the pathogen were further observed (Fig. 3 and Table 3). Once the antagonist (Trichoderma spp.) came into contact with the pathogen, it attached itself, coiled and strangulated the host hyphae (pathogen) on the surface in a Trichoderma-Phytophthora interrelationship
(Fig. 4). Both Trichoderma spp. grew faster and occupied more space than $P$. infestans.

The biocontrol isolates and the time period of growth had a significant effect on radial growth and percent growth inhibition of $P$. infestans (Fig. 4). The growth of the $P$. Infestans was significantly lower when cocultured with $T$. harzanium, than with $T$. asperellum. Growth of the pathogen was highest in the control treatment. Growth inhibition of the pathogen was highest when co-cultured with the $T$. harzanium compared to T. asperellum; while the control treatment showed no significant growth inhibition (Table $3)$.

In terms of radial growth of the pathogen, there was a general increase in growth over time, for all the treatments. Growth was significantly higher in the control treatment from the start of growth, up to the eighth day. Between the two Trichoderma isolates, $T$. Harzanium had significantly higher radial growth than $T$. asperellum, over the growth period of study (Fig. 5). Regarding the percent growth inhibition, the control did not inhibit growth of the pathogen from the day of culturing up to eighth day of growth.

For the Trichoderma isolates, the percent growth inhibition was higher during the initial days of growth, which then reduced and finally increased on the eighth day. At the end of the study period (day 8), growth inhibition was significantly, higher with $T$. harzanium than T. asperellum (Fig. 6). The laboratory assay

TABLE 2. Cultural and molecular characteristics of T. harzianum and T. asperellum isolated from the commercial products

\begin{tabular}{llcllc}
\hline Strain no. & $\begin{array}{l}\text { Expected } \\
\text { bioagent }\end{array}$ & $\begin{array}{c}\text { Sequence } \\
\text { length }\end{array}$ & Accession no. & Description & Identity (\%) \\
\hline GK2(R) & T. harzianum & 630 & KP064225.1 & Trichoderma harzianum & 95 \\
GK7(R) & T. harzianum & 633 & KU200440.1 & Meyerozyma caribbica & 95 \\
GK8(R) & T. harzianum & 600 & JK518925.1 & T. harzianum & 91 \\
GK9 & T. harzianum & 610 & JN255499.1 & Meyerozyma caribbica & 92 \\
GK15 & T. asperellum & 698 & LN846676.1 & T. asperellum & 90 \\
\hline
\end{tabular}

$\mathrm{R}=$ the reverse primer (ITS4) of the DNA region 
NJ 488 sites J-C 100 replication.

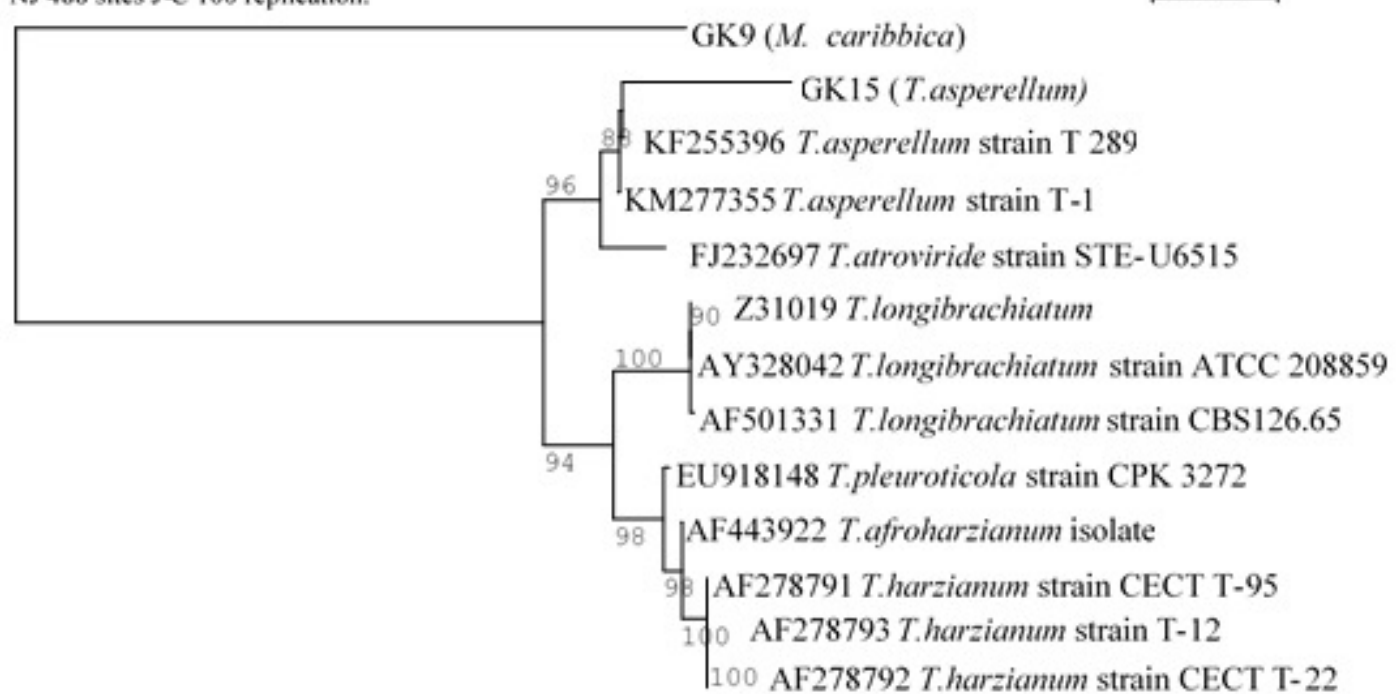

Figure 2. Phylogenetic tree of the Trichoderma harzianum and Trichoderma asperellum based on ITS-rDNA gene sequences.

TABLE 3. In vitro inhibition of Phytophthora infestans by Trichoderma harzianum and Trichoderma asperellum by dual culture method

\begin{tabular}{lcc}
\hline Isolate & Radial growth $(\mathrm{mm})$ & Growth inhibition $(\%)$ \\
\hline Trichodermaharzianum & $16.4 \mathrm{c}$ & $36.9 \mathrm{a}$ \\
Trichodermaasperellum & $18.5 \mathrm{~b}$ & $30.7 \mathrm{~b}$ \\
Control & $38.0 \mathrm{a}$ & $0.0 \mathrm{c}$ \\
& & 0.8 \\
\hline
\end{tabular}

showed variations in pattern and time duration of parasitism depending upon the pathogen encountered.

\section{Efficacy of antagonists in the greenhouse trial}

Interactions between antagonists and the pathogen. Disease severity across the soil types was significantly reduced by the combination of Trianum- $\mathrm{P}^{\circledR}($ T. harzianum $)$ and Trichotech $^{\circledR}$ (T. asperellum) (T4), and the single applications of the biocontrol agents (T2 or T3) $(\mathrm{P}<.0001)$ (Fig. 7). Trichotech ${ }^{\circledR}(T$. asperellum) (T3) significantly reduced disease severity compared to T. harzianum (Trianum$\left.\mathrm{P}^{\circledR}\right)(\mathrm{T} 2)(\mathrm{P}<.0001)$, but was not significantly different from their combination (T4) (P $<.0001)$. Disease severity in all soil types was highest in the control treatment (T0). Use of the chemical fungicide (T1) significantly reduced disease severity compared to the control (T0) $(\mathrm{P}<.0001)$. However, T1 had significantly higher disease severity than the biocontrol agents (T4, T2 and T3) $(\mathrm{P}<.0001)$ (Fig. 7).

Bungoma soil had the highest biomass; while Chuka soil showed the least biomass values (Fig. 8). In Bungoma, a combination of $T$. harzianum and T. asperellum revealed 


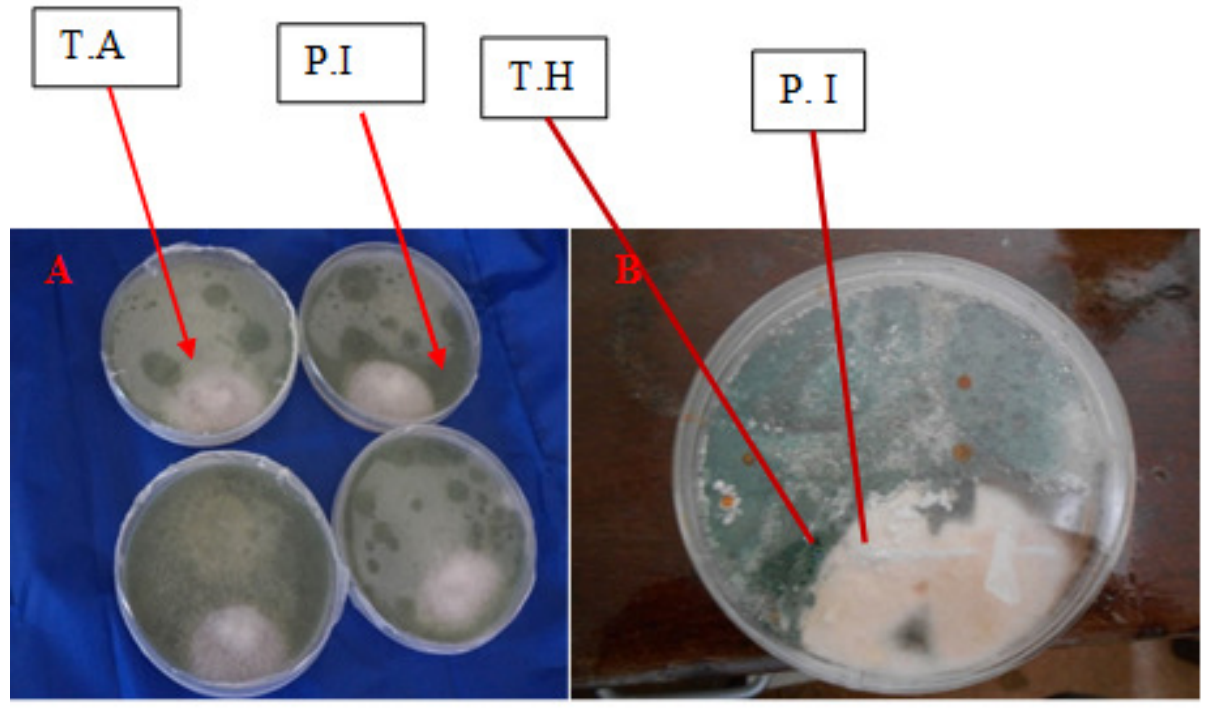

Figure 3. Effects of the antagonists on P. infestans. A = inhibition of growth of $P$. infestans (P. I) by $T$. asperellum (T. A) on replicated plates of dual cultures of P.I and T.A; B = inhibition of growth of $P$. infestans (P. I) by T. harzianum (T. H).

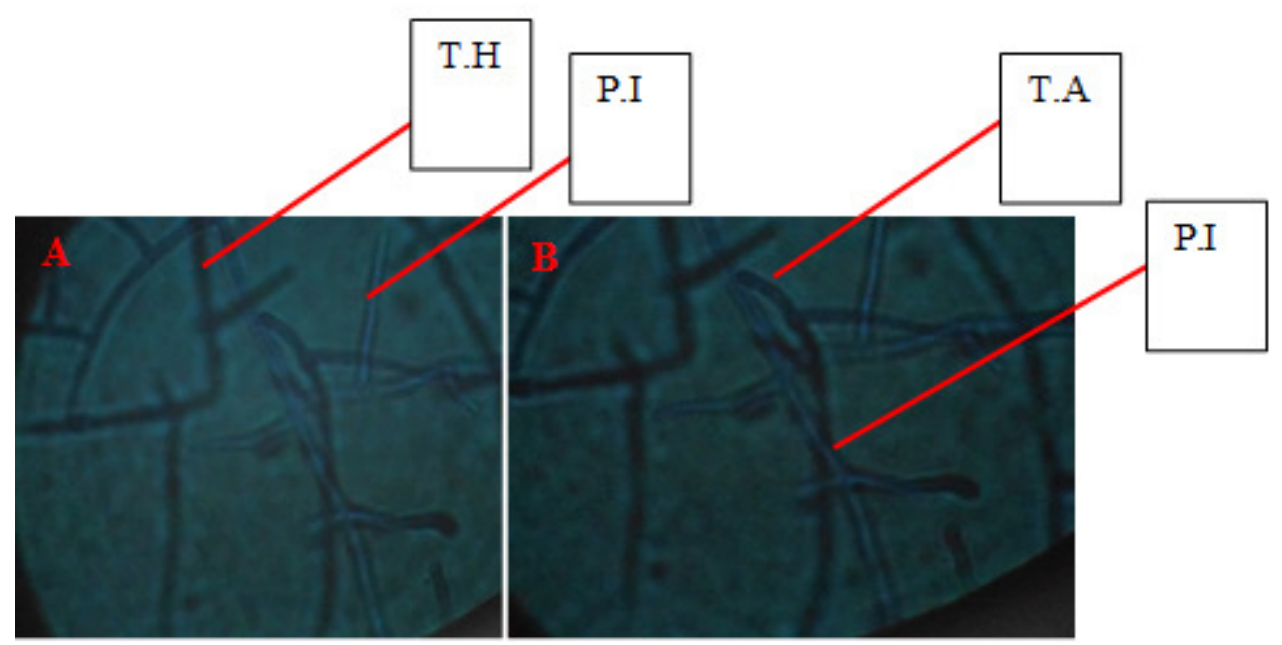

Figure 4. Hyphal interaction of antagonists with the pathogen. A=T. Harzianum (T.H) parasitizing P. infestans (P.I); B = T. Asperellum (T.A) parasitizing P. Infestans (P.I).

significantly higher biomass compared to all other treatments $(\mathrm{P}<.0001)$. In Chuka soils, T. asperellum showed significantly higher biomass than other treatments; while $T$. harzianum had significantly low values compared to the rest of the treatments.

In Egerton soil, single application of $T$. harzianum and T. asperellum had significantly higher biomass than the other treatments $(\mathrm{P}<.0001)$. The combination of the biocontrol agents (T4) revealed significantly lower biomass values compared to all other treatments including the controls in Egerton soil (P <.0001) (Fig. 8). 


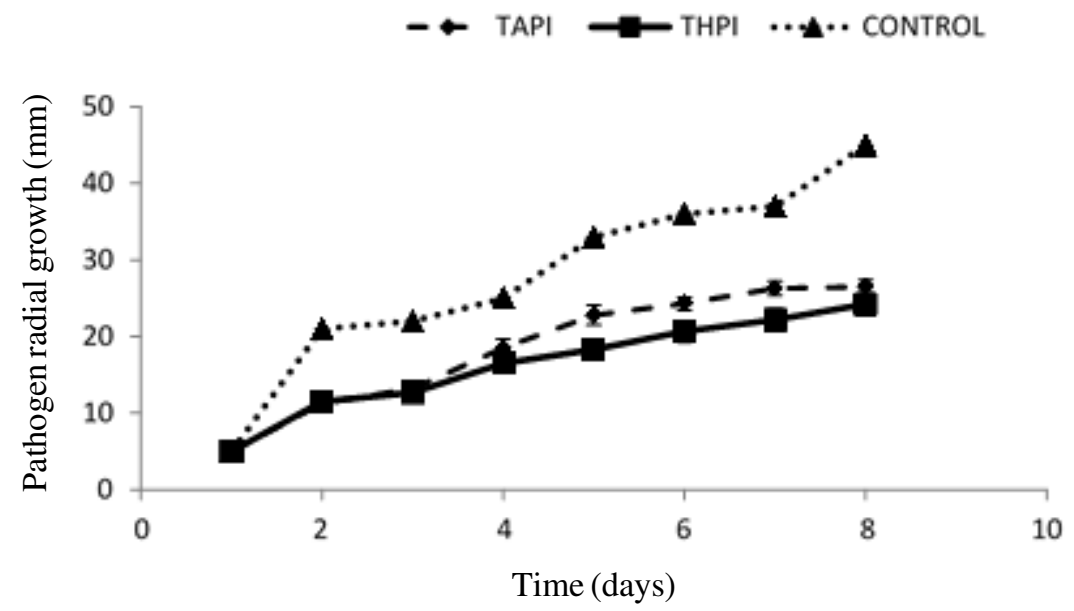

Figure 5. Effect of the biocontrol agents on the progression of the pathogen radial growth. Error bars represents the standard error of the means.

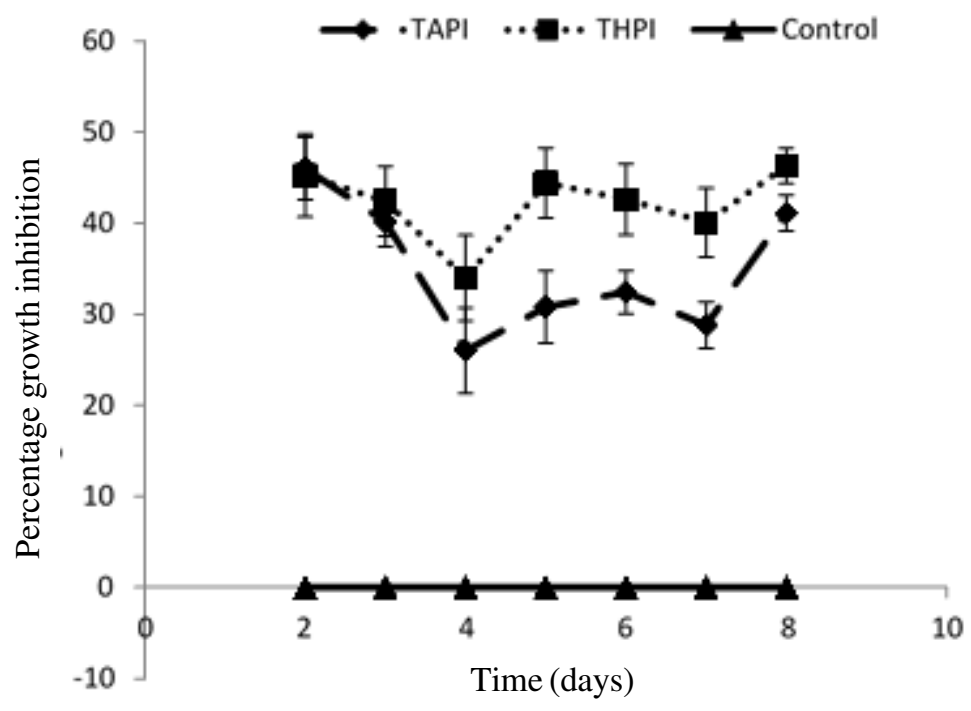

Figure 6. Effect of the biocontrol agents on the growth inhibition of the pathogen. Error bars represents standard error of the means.

\section{DISCUSSION}

Based onmorphological characteristics of the Trichoderma species, this study has confirmed that both the biocontrol commercial products under study contained both T. harzianum and T. asperellum. However, use of molecular characterisation only identified a few of the isolates as T. harzianum and T. asperellum. This discrepancy between the two characterisation is evidence that molecular characteristics are potentially superior diagnostic tools in identifying the Trichoderma ssp.

In the dual culture tests, the $T$. harzianum and $T$. asperellum isolates grew substantially faster than the $P$. infestans isolates, and speedily overcame the $P$. infestans isolates.All of the tested isolates of T. harzianum and $T$. asperellum significantly reduced radial growth 


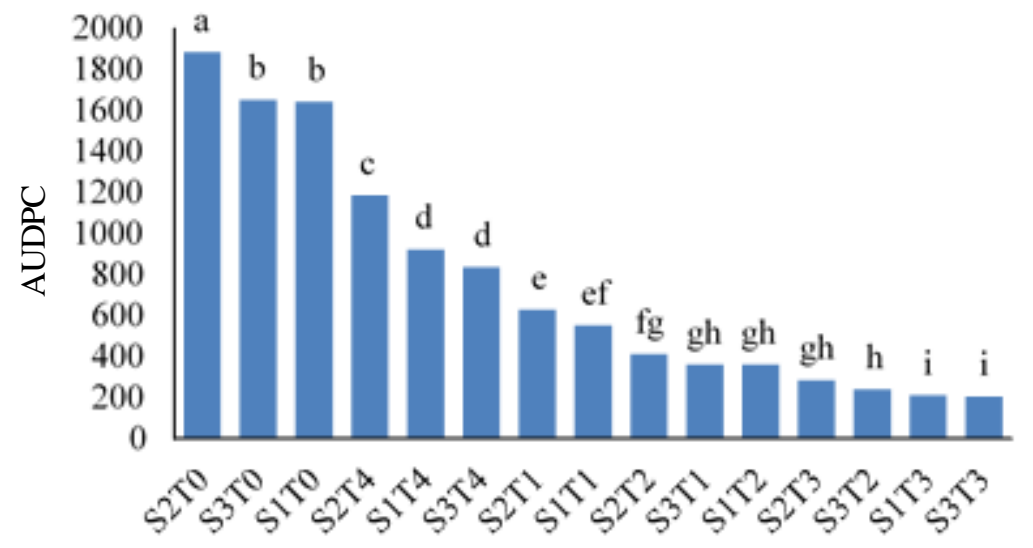

Treatment

Figure 7. Effect of the treatments on the disease severity (AUDPC) of tomatoes. S1-Ferralsols, S2Rhodic nitisols and S3- vitric andosols. Means with the same letter are not significantly different from each other at $\alpha=0.05$.

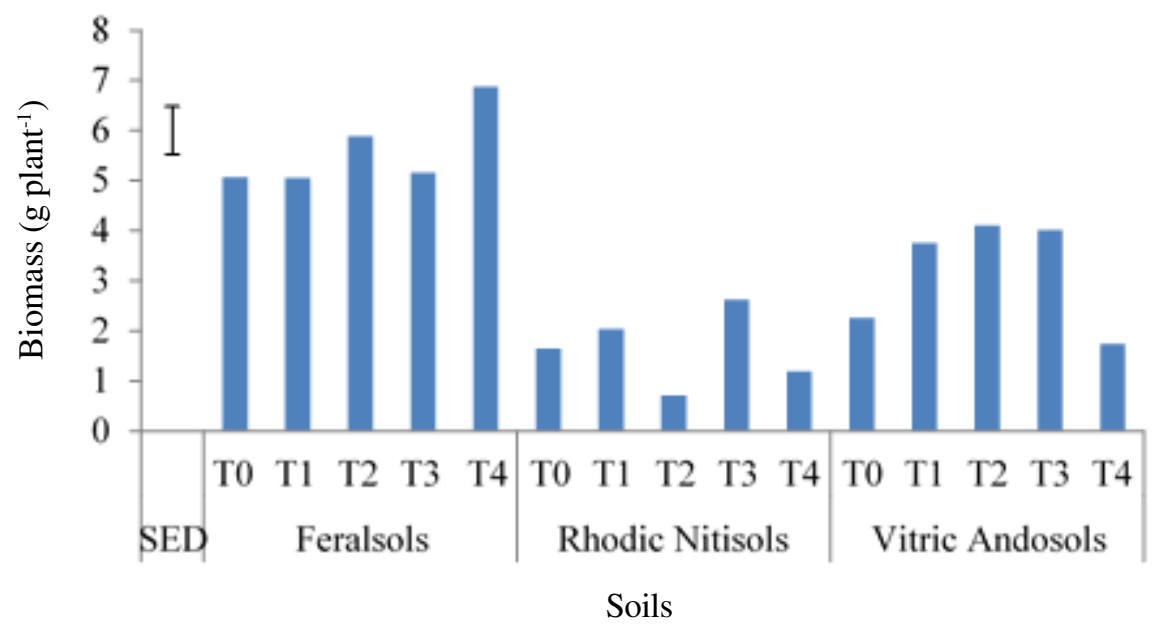

Figure 8. Effect of treatments on tomatoes biomass in three different soils. $\mathrm{T} 0=$ distilled water, $\mathrm{T} 1=$ Fungicide $\left(\right.$ Ridomil ${ }^{\circledR}$ Metalaxl-M), T2 $=$ T.harzianum $\left(\right.$ Trianum- $\left.\mathrm{P}^{\circledR}\right), \mathrm{T} 3=$ T. asperellum $\left(\right.$ Trichotech $^{\circledR}$ ) and $\mathrm{T} 4=\mathrm{T} 2+\mathrm{T} 3$. Bars are means of plant biomass and standard error of the difference (SED).

and inhibited growth of the pathogen. These isolates overgrew and sporulated on the pathogen colonies. This observation might be attributed to the rapid growth ability of the Trichoderma species, giving it an added advantage in competing for nutrients and space with the pathogen (Pandey et al., 2016; O'Brien, 2017; Adnan et al., 2019; Dukare et al., 2019). Faruk and Rahman (2015) also reported that the Trichoderma sp. were able to suppress the pathogen's colony by rapid growth of the Trichoderma sp. This may have led to starvation of the pathogen due to the competition for the limited resources resulting to the death of the $P$. infestans (Sempere and Santamarina, 2007). In the region of interaction, the antagonists coiled and strangulated the pathogen, resulting into an abnormal morphology of the pathogen mycelia, which suggests the existence of strong 
mycoparasitism between the Trichoderma (antagonist) and the pathogen (Ghorbanpour et al., 2018).

Treatments with the Trichoderma spp., either as single applications or a combination of $T$. harzianum and T. Asperellum had significantly reduced disease severity compared to the absolute control and the chemical fungicide. The reduced disease severity could be attributed to the Trichoderma's rhizosphere competence and competitive ability (Tsahouridou and Thanassoulopoulos, 2002); and induction of plant defence mechanisms (Sharma, 2017).

These results corroborate numerous studies, where $T$. harzianum and $T$. asper-ellumisolates showed high capabilities for being useful biocontrol agents (Saravanakumar et al., 2016; Amira et al., 2017; Pascale et al., 2017).

Results from this study have shown that growth of tomato is enhanced by the application of the biocontrol agents. The increased growth in terms of tomato biomass may be as a result of production of growth hormones (Contreras-Cornejo et al., 2014), increased uptake of nutrients or enhancement of root growth (Viterbo et al., 2002). Menezes-Blackburn et al. (2014), while working on Trichoderma spp., reported an increase in plant growth due to the ability of the microbe to help in bioavailability of different mineral nutrients via solubilisation or chelation. Therefore, these growth promotion attributes of the Trichoderma spp. may have led to the enhanced tomato growth in the present study.

Although no significant interactions were observed between soil type and the antagonists, variations between different soil types in terms of soil characteristics has been shown elsewhere to influence the antagonists' effects on the growth parameters of the tomato (Van Agtmaal et al., 2018). For example, in the Feralsols, a combination of biocontrol agents increased tomato biomass and had the least disease severity values over all other treatments. This site (Bungoma) had been characterized with the highest $\mathrm{N}$ and $\mathrm{P}$ in comparison to the other two sites (Table 1). Chuka site (Rhodic Nitisols) characterised by the least soil $\mathrm{pH}$ and plant available $\mathrm{P}$, of the three on the other hand, had least effect of treatments on the growth parameters.

Trichoderma asperellum was most effective in promoting the tomato biomass compared to $T$. harzianum or the combination of both. This implies that the T. asperellum isolates could be more tolerant to lower soil $\mathrm{pH}$ and that acidic soil conditions compared to $T$. harzianum. This could also be the reason why the combination of the two biocontrol agents performed poorer than the latter alone in the same soil. Abiotic factors such as $\mathrm{pH}$ have adverse effects on bio-efficacy of Trichoderma spp. (Zehra et al., 2017).

Egerton soil (Vitric Andosols) characterised by the highest carbon contents had a moderate promotion effect on tomato biomass by the biocontrol agents. Here, the single applications of the biocontrol agents and the chemical fungicide performed better than the combinations.

Soil type with diverse nutrient status on the stimulatory effectiveness of microbial inoculants has been shown to be key for effective root inoculation and stimulation of plant growth (de Souza et al., 2015). The chemical composition of soil controls the survival and biological activity of microorganisms (Wang et al., 2017; Van Agtmaal et al., 2018). Trichoderma spp. efficiency, therefore, is determined by environmental health that could affect not only their survival in the soil, but also their ability to maintain bio-control capacity (Nieto-Jacobo et al., 2017). It appears that in soils where the abiotic environment is not greatly limiting, the factors of primary importance are those involving competition, antagonism and synergism (O'Brien, 2017). This therefore underscores the importance of providing the optimal soil conditions such as the correct 
nutrients and $\mathrm{pH}$ ranges that will boost the performance of the BCA in the management of the $P$. infestans in tomato production.

\section{CONCLUSION}

Isolated Trichoderma harzianum and $T$. asperellum strain from Trianum- $\mathrm{P}^{\circledR}$ and Trichotech $^{\circledR}$, respectively have the ability to antagonise Phytophthora infestans in tomato. It can beconcluded from the present study that, although both the Trichoderma strains applied individually reduce disease severity, combining $T$. harzianum and T. asperellum shows greater protective effects on tomato that are exposed to $P$. infestans under greenhouse conditions as shown by the AUDPC results. Soil type also influences the response of tomato to application of the biocontrol. Tomato biomass is higher and disease severity less in Ferralsol compared to other soil types.

\section{ACKNOWLEDGEMENT}

This research was supported through a subgrant by the International Institute of Tropical Agriculture (IITA) to Egerton University under the COMPRO-II Project. The authors are grateful to the MasterCard Foundation and Regional Universities Forum for Capacity Building in Agriculture (RUFORUM) for funding research and publication cost through the Transforming African Agricultural Universities to meaningfully contribute to Africa's growth and development (TAGDev) Program.

\section{REFERENCES}

Adnan, M., Islam, W., Shabbire, A., Khang, K.A., Ghram, H.A., Huang, Z., Chenb, H.Y.H. and Lu, G. 2019. Plant defense against fungal pathogens by antagonistic fungi with Trichoderma in focus. Microbial Pathogenesis 129:7-18.
Amira, M.B., Lopez, D., Mohamed, A.L., Khouaja, A., Chaar, H., Fumanal, B., Gousset-Dupont, V., Bonhomme, L., Label, P., Goupil, P., Ribeiro, S., Pujade-Renaud, V., Julien, J., Auguin, D. and Venisse, J. 2017. Beneficial effect of Trichoderma harzianum strain Ths97 in biocontrolling Fusariumsolani causal agent of root rot disease in olive trees. Biological Control 10:70-78.

Carter, J.L. 2011. Yeast plate count protocol. http://biology.clc.uc.edu/. Accessed 16 June 2017.

Chowdappa, P., Kumar, N.B.J., Madhura, S., Kumar, M.S.P., Fry, W.E., Squires, J.N., Cooke, D.E.L. and Myers, K.L. 2013. Emergence of 13_A2 Blue Lineage of Phytophthora infestans was responsible for severe outbreaks of late blight on tomato in South-West India. Journal of Phytopathology 161:49-58.

Contreras-Cornejo, H.A., Macías-Rodríguez, L.I., Alfaro-Cuevas, R. and López-Bucio, J. 2014. Trichoderma spp. improve growth of Arabidopsis seedlings under salt stress through enhanced root development, osmolite production, and $\mathrm{Na}+$ elimination through root exudates. Molecular Plant-Microbe Interaction 27: 503-514.

de Souza, R., Ambrosini, A. and Passaglia, L.M.P. 2015. Plant growth-promoting bacteria as inoculants in agricultural soils. Genetics and Molecular Biology 38(4):401-419.

Dukare, A.S., Paul, S., Nambi, V.E., Gupta, R.K., Singh, R., Sharma, K. and Vishwakarma, R.K. 2019. Exploitation of microbial antagonists for the control of postharvest diseases of fruits: A review. Critical Reviews in Food Science and Nutrition 59(9):1498-1513.

Faruk, M.I. and Rahman, M.L. 2015. Management of tomato seedling rot disease (Rhizoctonia solani) in seedbed with Trichoderma harzianum bio-fungicide. 
Agricultural Science Research Journal 5: 14-20.

Fatima, K., Noureddine, K., Henni, J.E and Mabrouk, K. 2015. Antagonistic effect of Trichoderma harzianum against Phytophthora infestans in the North-west of Algeria. International Journal of Agronomy and Agricultural Research 6(4): 44-53.

Galtier, N., Gouy, M. and Gautier, C. 1996. SEA VIEW and PHYLO_ WIN: Two graphic tools for sequence alignment and molecular phylogeny. CABIOS 12(6):543548.

Gelfand, D.H. and White, T.J. 1990. Thermostable DNA polymerases. In: Innis, M.A., Gelfand, D.H., Sninsky, J.J. and White, T.J. (Eds.). PCR Protocols, a Guide to Methods and Applications. California: Academic Press. pp. 129-141.

Ghorbanpour, M., Omidvari, M., AbbaszadehDahaji, P., Omidvar, R. and Kariman, K. 2018. Mechanisms underlying the protective effects of beneficial fungi against plant diseases. Biological Control 117:147-157.

Gyawali, K. 2018. Pesticide uses and its effects on public health and environment. Journal of Health Promotion 6:28-36.

Haynes, K.G. and Weingartner, D.P. 2004. The use of area under the disease progress curve to assess resistance to late blight in potato germplasm. American Journal of Potato Research 81:137-141.

Heneberg, P., Svoboda, J. and Pech, P. 2018. Benzimidazole fungicides are detrimental to common farmland ants. Biological Conservation 221:114-117.

Köhl, J., Kolnaar, R. and Ravensberg, W.J. 2019. Mode of action of microbial biological control agents against plant diseases: Relevance beyond efûcacy. Frontiers in Plant Science 10:845.

Lamichhane, J.R., You, M.P., Laudinot, V., Barbetti, M.J. and Aubertot, J. 2020. Revisiting sustainability of fungicide seed treatments for field crops. Plant Diseases 104:610-623.

Larkin, M.A., Blackshields, G., Brown, N.P., Chenna, R., McGettigan, P.A., McWilliam, H. and Higgins, D.G. 2007. Clustal W and Clustal X version 2.0. Bioinformatics 23(21):2947-2948.

Latz, M.A.C., Jensen, B., Collinge, D.B and Jørgensen, H.J.L. 2018. Endophytic fungi as biocontrol agents: Elucidating mechanisms in disease suppression. Plant Ecology and Diversity 11(5-6):555-567.

Masinde, A.O.A., Kwambai, K.T. and Wambani, N.H. 2011. Evaluation of tomato (Lycopersicon esculentum L.) variety tolerance to foliar diseases at Kenya Agricultural Research Institute CentreKitale in North West Kenya. African Journal of Plant Science 5(11):676-681.

Menezes-Blackburn, D., Jorquera, M.A., Gianfreda, L., Greiner, R., de la Luz and Mora, M. 2014. A novel phosphorus biofertilization strategy using cattle manure treated with phytase-nanoclay complexes. Biology and Fertility of Soils 50:583-592.

Mbuthia, L.W., Kiirika, L.M., Afolayan, G. and Henning, V.A. 2019. Interactive effects of arbuscularmycorrhiza fungi Glomusintraradices and Trichoderma harzianum against Fusarium wilt of tomato. International Journal of Biosciences 15(1): 251-268.

Momanyi, N.V., Keraka, N.M, Abong'o, A.D., and Warutere, N.P. 2019. Types and classification of pesticides used on tomatoes grown in Mwea irrigation scheme, Kirinyaga County, Kenya. European Journal of Nutrition and Food Safety 11(2):83-97.

Nieto-Jacobo, M.F., Steyaert, J.M., SalazarBadillo, F.B., Nguyen, D.V., Rostás, M., Braithwaite, M., De Souza, J.T., JimenezBremont, J.F., Ohkura, M., Stewart, A. and Mendoza-Mendoza, A. 2017. Environmental growth conditions of Trichoderma spp. Affects indole acetic 
acid derivatives, volatile organic compounds, and plant growth promotion. Frontiers in Plant Science 8:102. doi: 10.3389/fpls.2017.00102

Nourulaini, R.N., Moftah, B.N., Lah, T.N., Nawi, A.H., Kadir, M.O. and Paiko, M.A. 2012. Maximizing glucose production from palm kernel cake (PKC) from which residual oil was removed supercritically via solid state fermentation (SSF) method using Trichoderma reesi isolate Pro-A1. The Internet Journal of Microbiology. doi: $10.5580 / 2 \mathrm{a} 82$.

O'Brien, P. A. 2017. Biological control of plant diseases. Review. Australasian Plant Pathology doi: 10.1007/s13313-017-04814.

Okalebo, J.R., Gathua, K.W. and Woomer, P.L. 2002. Laboratory Methods of Soil and Plant Analysis: A Working Manual, KARI, SSSEA, TSBF, SACRED Africa, Second Edition. Nairobi: Moi University, Kenya. $128 p$.

Pandey, V., Shukla, A., Kumar, J. 2016. Physiological and molecular signalling involved in disease management through Trichoderma: An effective biocontrol paradigm. In: Kumar, P., Gupta, V., Tiwari A. and Kamle, M. (Eds.). Current trends in plant disease diagnostics and management practices. Fungal Biology. Springer, Cham: pp. 57-69.

Pascale, A., Vinale, F., Manganiello, G., Nigro, M., Lanzuise, S., Ruocco, M., Marra, R., Lombardi, N. and Woo, S.L. 2017. Trichoderma and its secondary metabolites improve yield and quality of grapes. Crop Protection 92:176-181.

Perveen, K. and Bokhari, N.A. 2012. Antagonistic activity of Trichoderma harzianum and Trichoderma viridae isolated from soil of date palm field against Fusarium oxysporum. African Journal of Microbiology Research 6:3348-3353.

Poornima, S. 2011. Evaluation of disease control and plant growth promotion potential of bio-control agents on Pisum sativum and comparison of their activity with popular chemical control agentCarbendazim. Journal of Toxicology and Environmental Health Sciences 3:127-138.

Saravanakumar, K., Yu, C., Dou, K., Wang, M., Li, Y. and Chen, J. 2016. Synergistic effect of Trichoderma-derived antifungal metabolites and cell wall degrading enzymes on enhanced biocontrol of Fusarium oxysporum f. sp. cucumerinum. Biological control 94:37-46.

SAS Institute. 2014. SAS 9.4 Output Delivery System: User's Guide. SAS Institute Inc., Cary, North Carolina. USA.

Sempere, F. and Santamarina, M. 2007. In vitro biocontrol analysis of Alternaria alternata (Fr.) Keissler under different environmental conditions. Mycopathologia 163:183-190.

Sharma, K.K. 2017. Induction of systemic resistance (ISR) against sheath blight of rice caused by Rhizoctonia solani Kuhn using biological seed treatment with Trichoderma. Journal of Applied and Natural Science 9(3):1861-1865.

Sharma, K.K. 2018. Trichoderma in Agriculture: An overview of global scenario on research and its application. International Journal of Current Microbiology and Applied Sciences 7(8): 1922-1933.

Singh, S., Pandey, R.K. and Goswami, B.K. 2013. Bio-control activity of Purpureocillium lilacinum strains in managing root-knot disease of tomato caused by Meloidogyne incognita. Biocontrol Science and Technology 23(12):1469-1489.

Starke Ayres. 2014. Tomato production guideline. https://www.starkeayres.co.za/ com_variety_docs/Tomato-ProductionGuideline-2014.pdf. Accessed 19 September 2018.

Tamura, K., Stecher, G., Peterson, D., Filipski, A. and Kumar, S. 2013. MEGA6: Molecular evolutionary genetics analysis version 6.0. Molecular Biology and Evolution 30: 2725-2729. 
Tsahouridou, P.C. and Thanassoulopoulos, C.C. 2002. Proliferation of Trichoderma koningii in the tomato rhizosphere and the suppression of damping-off by Sclerotiumrolfsii. Soil Biology and Biochemistry 34(6):767-776.

Van Agtmaal, M., Straathof, A., Termorshuizenc, A., Lievens, B., Hoûande, E. and Boer, W. 2018. Volatile-mediated suppression of plant pathogens is related to soil properties and microbial community composition. Soil Biology and Biochemistry 117:164-174.

Viterbo, A., Montero, M., Ramot, O., Friesem, D., Monte, E., Liobell, A. and Chet, I. 2002. Expression regulation of the endochitinase chit 39 from Trichoderma asperellum (T. harzianum T203). Current Genetics 42:114-122.
Wang, R., Zhang, H., Sun, L., Qi, G. Chen, S. and Zhao, X. 2017. Microbial community composition is related to soil biological and chemical properties and bacterial wilt outbreak. Scientific Reports 7:343. doi:10.1038/s41598-017-00472-6.

White, T.A., Chen, W. and Shroeder, K.L. 2019.Assessing the contribution of ethaboxam in seed treatment cocktails for the management of the metalaxyl-resistant Pythiumultimum in Pacific Northwest Spring wheat production. Crop Protection 115:7-12.

Zehra, A. Dubey, M.K., Meena, M. and Upadhay, R.S. 2017.Effect of different environmental conditions on growth and sporulation of some Trichoderma species. Journal of Environmental Biology 38:1972013. 